\title{
Operations Research: International Conference Series
}

\section{Identification of Pathogenic Bacteria on Carp Commodities (Cyprinus carpio) at Quality Control and Fishery Product Safety Agency (BKIPM) of Bengkulu}

\author{
Risky Hadi Wibowo ${ }^{1 *}$, Sipriyadi ${ }^{2}$, Welly Darwis ${ }^{3}$, Ema Kurnia Putri ${ }^{4}$, Nadya Rosianti ${ }^{5}$, Della Indah \\ Medani $^{6}$, Gustina Dwi Wulandari ${ }^{7}$, Kukuh Andias Purbianto ${ }^{8}$, Novi Susianti ${ }^{9}$ \\ ${ }^{1 * 2,3}$ Department of Biology, Faculty of Mathematics and Natural Sciences, Universitas Bengkulu, Kandang Limun, Bengkulu \\ 38112, Indonesia. \\ ${ }^{4,5,6,7}$ Undergraduate Student, Department of Biology, Faculty of Mathematics and Natural Sciences, Universitas Bengkulu, \\ Kandang Limun, Bengkulu 38112, Indonesia. \\ ${ }^{8,9}$ Quality Control and Fishery Product Safety Agency (BKIPM) of Bengkulu, Bengkulu, 38213, Indonesia.
}

*Corresponding author email: riskyhadiwibowo80@gmail.com

\begin{abstract}
Carp (Cyprinus carpio) is a type of freshwater fish that is widely cultivated. The increase in the amount of production and trade in freshwater fishery commodities both for consumption in Bengkulu will potentially increase the risk of entry and spread of pests and diseases in fish, which at the same time will be a threat that can endanger and damage the sustainability of fishery biological resources. Bacteria that infect fish can inhibit the expected production targets, which is an outbreak of pathogenic fish disease caused by bacteria. This study aims to identify pathogenic bacteria that infect Carp (C. carpio). Carp were obtained from fish traders at Panorama Market, Bengkulu City. Carp samples were selected based on clinical symptoms that were no longer healthy. Isolation of bacteria from Carp's organs using Triptic Soy Agar (TSA) media. The isolates were screened by morphological characters and biochemical test. The results of this study showed that total of 2 bacteria were isolated. Based on biochemical tests carried out such as the Simmons Citrate test, Triple Sugar Iron Agar, Oxidative-Fermentative, Motility Indol Ornithine, Lysine Iron Agar, MR-VP, urea, catalase, oxidase, gelatin, confectionery test, and Rimmler-Shotts test, pathogenic isolates Sp 1. in the sample have a close relationship with Plesiomonas shigelloides while the pathogenic isolates Sp 2. and Sp 3. have a close relationship with Aeromonas hydrophila.
\end{abstract}

Keywords: Cyprinus carpio, Aeromonas hydrophila, Plesiomonas shigelloides

\section{Introduction}

The potential for freshwater fish cultivation is very large to be developed, one of which has the potential to cultivate freshwater fish commodities as carp. Carp (Cyprinus carpio) is one of the most widely cultivated types of freshwater cultivated fish because it has good prospects for development because it is popular with the community and has high economic value (Yulvizar et al., 2014). An increase in the amount of production and trade in carp commodities in Bengkulu has the potential to increase the risk of entry and spread of pests and diseases in fish, which at the same time will be a threat that can endanger and damage the sustainability of fishery biological resources.

One of the most dangerous diseases is bacterial infection or bacterial disease. Bacterial diseases that may attack freshwater fish include Aeromonas hydrophila, A. salmonicida, Pseudomonas anguilliseptica, Streptococcus (Murwantoko et al., 2013). Disease cases caused by bacteria can cause huge losses to cultivation activities, for example, mass mortality. One of the cases of the Motile Aeromonas Septicemia (MAS) disease outbreak was caused by Aeromonas hydrophila. Based on the description above, it is necessary to conduct research on the identification of bacteria in fisheries commodities, especially carp. This aims to determine the types of phatogenic bacteria that can attack carp and efforts to prevent them. 


\section{Materials and Methods}

\subsection{Materials}

The tools and materials used in this study were Petri dishes, test tubes, Erlenmeyer, loop needles, glass objects, incubators, refrigerators, analytical scales, ovens, test tube racks, trays, spatulas, measuring cups, spray bottles, surgical instruments, beakers glass, bunsen burner, micropipette, tube, UV-Laminar flow-hood, magnetic stirrer, hotplate, autoclave, stationery, Carp (Cyprinus carpio), 70\% alcohol, spritus, absolute alcohol, iodine, paraffin, oxidase paper, $\mathrm{KOH} \mathrm{40 \% ,3 \%} \mathrm{KOH}$ solution, 3\% H2SO2 solution, aqua dest, Kovack's solution, Methyl Red solution, $\alpha$-naphthol solution, paraffin, Simmons Citrate Agar media, Triptic Soy Agar (TSA), Triple Sugar Iron Agar, Oxidative-Fermentative media, Motility Indole Ornithine, Lysine Iron Agar, MR-VP, Urease, Phenol Red Broth Base, Glucose, Maltose, Lactose, Mannitol, Sorbitol, Gelatin, RS Media, cotton, tissue, label paper, wrapping paper, matches, rubber bands, aluminum foil, and bacteria identification forms.

\subsection{Carp (Cyprinus carpio) Sample Collection}

Samples were obtained from fish traders at Panorama market, Bengkulu City. Carp samples selected that had clinical symptoms that were no longer healthy. Furthermore, in living conditions, samples were analyzed at the Testing Laboratory, Fish Quarantine Station, Quality Control, and Safety of Fishery Products (SKIPM) Bengkulu.

\subsection{Isolation of Target Pathogenic Bacteria from Carp (Cyprinus carpio) Samples}

The body surface of the fish was cleaned with iodine using a clean tissue. Then, the stomach dissected to reveal the internal organs. Furthermore, bacteria were isolated from the target organs, namely the kidneys and liver using an inoculation loop that had been glazed over the bunsen onto the TSA media with streak method and incubated in the incubator for $1 \times 24$ hours at room temperature. Isolates grown on the media were inoculated and purified.

\subsection{Identification of Phatogenic Bacterial Colony Characteristics by Biochemical Test}

Identification of phatogenic bacterial colonies using biochemical test, such as Potassium hydroxide Test, catalase test, oxidase test, gelatin test, Simmons Citrate test, Triple Sugar Iron Agar test, OF test, MIO test, Lysine Iron Agar test, MR-VP test, Urea test, Carbohydrate Tests including glucose, maltose, lactose, mannitol, and sorbitol as well as Rimlerr-Shottsmedia test.

\subsection{Identification of Phatogenic Bacterial Isolates from Target Organs, Kidney and Liver of Carp (Cyprinus carpio)}

Identification of the type of phatogenic bacteria carried out by adjusting the test results and characteristics of the bacteria that were available on the identification sheet using the Manual for the Identification of Medical Bacteria (Cowan, \& Steel, 1993) and the Standard Method of HPIK Examination, PUSKARI (Septiama et al., 2010).

\section{Results and Discussion}

External morphology of Carp (Cyprinuscarpio) has wounds or red spots on the body surface of the fish and loss of scales. The symptoms of fish attacked by the bacterium Aeromonashydrophila show wounds (red spots) on the body surface, bleeding in the gills, and a distended stomach. Observation of Bacterial Colony Morphology in Carp can be seen in (Table 1) and (Figure 2) (Pratama et al., 2017).

Table 1.Identification of Phatogenic Bacterial Colony Morphology

\begin{tabular}{cccc}
\hline Bacterial & \multicolumn{3}{c}{ Isolated Organs } \\
\cline { 2 - 4 } Morphology & Heart & Liver & Kidney \\
\hline Color & Cream & Cream & Cream \\
Margin & Entire & Entire & Entire \\
Elevation & Convex & Convex & Convex \\
Form & Circular & Circular & Circular \\
\hline
\end{tabular}




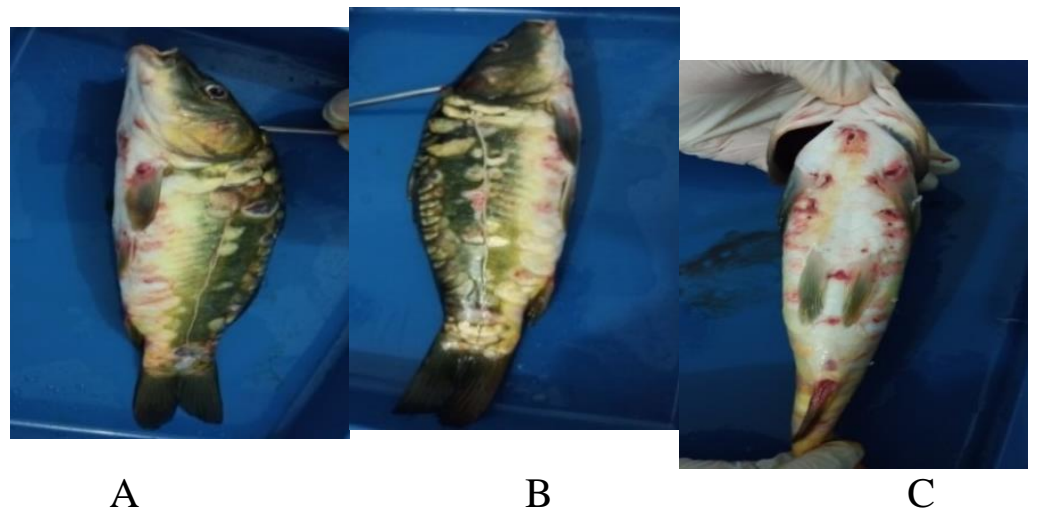

Figure 1. External morphology of the body of a Carp (Cyprinus carpio) on the (A) Left side 1,

(B) Right side (C) Bottom side

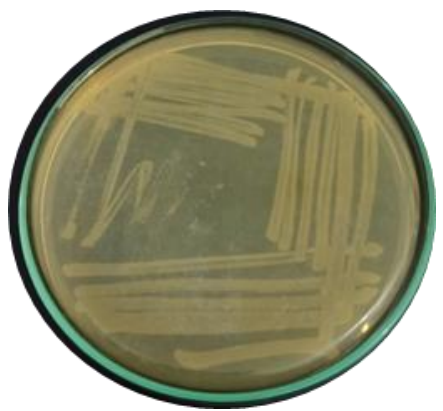

A

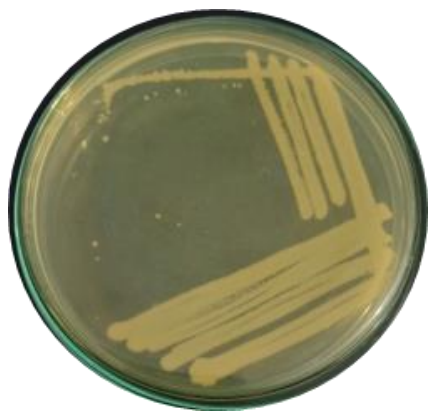

B

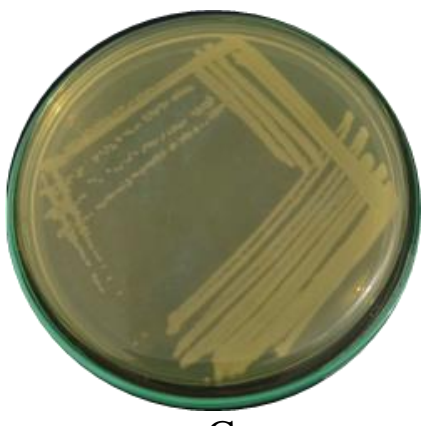

$\mathrm{C}$

Figure 2. Phatogenic Bacterial isolates from sample organs grown on Trypticase Soy Agar (TSA) media and incubated at $25^{\circ} \mathrm{C}$ for $1 \times 24$ hours (A) Heart, (B) Liver (C) Kidney in Carp (Cyprinus carpio).

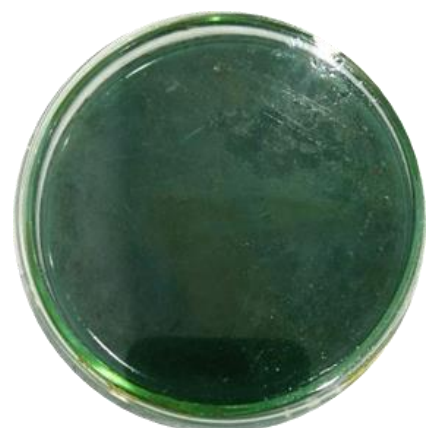

A

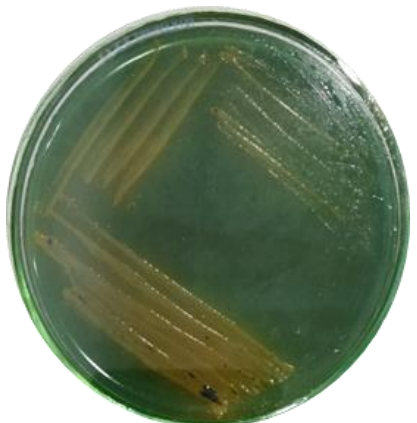

B

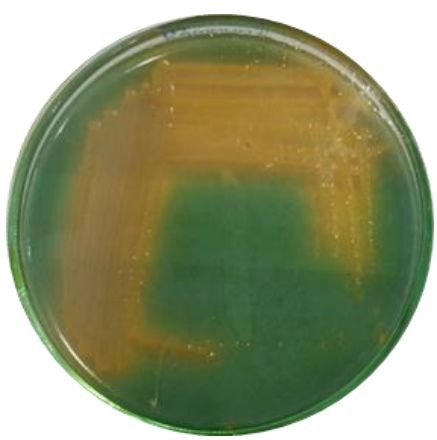

C

Figure 3. Phatogenic Bacterial isolates from sample organs grown on Rimlerr-Shotts (RS) media and incubated at $25^{\circ} \mathrm{C}$ for $1 \times 24$ hours (A) Heart, (B) Liver (C) Kidney in Carp (Cyprinus carpio).

Table 2.Identification of phatogenic bacteria by biochemical test

\begin{tabular}{lcccc}
\hline \multirow{2}{*}{ Biochemical Test } & \multicolumn{3}{c}{ Isolated Organs } & \multirow{2}{*}{ Note } \\
\cline { 2 - 5 } & Heart & Liver & Kidney & \\
\hline Potassium & + & + & + & Solution be viscous and \\
hydroxide Test & (Gram-negative) & $($ Gram-negative $)$ & $($ Gram-negative $)$ & form a mucoid string \\
Oxidase Test & + & + & + & purple color \\
Catalase Test & + & + & + & Bubbles of oxygen \\
\hline
\end{tabular}

The three phatogenic bacterial isolates from organ samples were gram-negative bacteria, catalase-positive with the formation of gas bubbles because the bacteria could produce catalase enzymes, and able to decompose $\mathrm{H}_{2} \mathrm{O}_{2}$ (Hydrogen Peroxide), and positive oxidase to produce a purple color on oxidase paper. Gram-negative bacterial cells will break down so that they will produce mucus that comes from bacterial fat, while Gram-positive will not produce mucus. 
Tabel 3. Identification of Phatogenic bacteria by biochemical test

\begin{tabular}{|c|c|c|c|c|c|c|}
\hline \multirow{2}{*}{\multicolumn{2}{|c|}{ Biochemical Test }} & \multicolumn{3}{|c|}{ Isolated Organs } & \multicolumn{2}{|c|}{ Positive Control } \\
\hline & & Heart & Liver & Kidney & $\begin{array}{c}\text { Aeromonas } \\
\text { hydrophila }(1)\end{array}$ & $\begin{array}{l}\text { Plesiomonasshi } \\
\text { gelloides }(2)\end{array}$ \\
\hline \multirow{3}{*}{ MIO Test } & Motility & + & + & + & + & + \\
\hline & Indole & + & + & + & + & + \\
\hline & Ornithine & + & - & - & - & + \\
\hline \multicolumn{2}{|c|}{ Gelatin Hydrolysis Test } & + & - & - & + & + \\
\hline \multirow{2}{*}{ MR-VP Test } & MR & + & - & - & No data & No data \\
\hline & VP & - & + & + & Variable & - \\
\hline \multirow{4}{*}{$\begin{array}{l}\text { Carbohydrat } \\
\text { e Tests }\end{array}$} & Glucose & + & + & + & + & + \\
\hline & Lactose & + & - & - & Variable & + \\
\hline & Maltose & + & + & + & No data & No data \\
\hline & Mannitol & + & + & + & No data & + \\
\hline \multirow{2}{*}{\multicolumn{2}{|c|}{$\begin{array}{l}\text { Sorbitol } \\
\text { Oxidative-Fermentative } \\
\text { Test }\end{array}$}} & - & - & - & Variable & - \\
\hline & & $\mathrm{F}$ & $\mathrm{F}$ & $\mathrm{F}$ & $\mathrm{F}$ & $\mathrm{F}$ \\
\hline \multirow{3}{*}{$\begin{array}{ll}\text { Triple } & \text { Sugar } \\
\text { Iron } & \text { Agar } \\
\text { Test } & \end{array}$} & Slunt/Butt & $\mathrm{K} / \mathrm{A}$ & $\mathrm{K} / \mathrm{A}$ & $\mathrm{K} / \mathrm{A}$ & No data & No data \\
\hline & $\mathrm{H}_{2} \mathrm{~S}$ & - & - & - & + & - \\
\hline & Gas & - & + & + & No data & No data \\
\hline \multicolumn{2}{|c|}{$\begin{array}{l}\text { Simmons Citrate Agar } \\
\text { Test }\end{array}$} & - & + & + & + & - \\
\hline $\begin{array}{l}\text { Lysine } \\
\text { Iron }\end{array}$ & Lysine & - & + & + & + & - \\
\hline $\begin{array}{l}\text { Agar } \\
\text { Test }\end{array}$ & Lysine & + & - & - & - & + \\
\hline \multicolumn{2}{|l|}{ Urea Test } & - & + & + & No data & - \\
\hline \multicolumn{2}{|c|}{ Rimler-Shotts Agar } & - & + & + & + & - \\
\hline
\end{tabular}

Control sources: 1 . Phatogenic bacterial identification book from the testing laboratory, Fish Quarantine Station, Bengkulu Fishery Product Quality and Safety Control.

2. Identification results from the research of Behera et al. (2018)

In the motility test, the three sample isolates have positive results, which means that the bacteria were motile. In the Indol test, the three isolates samples have positive results, which means that the isolate bacteria were able to produce indole from the amino acid tryptophan through the tryptophanase enzyme. Ornithine test results, bacterial isolates from heart sample organs showed positive test results, while bacterial isolates from liver and kidney sample organs showed negative test results. Bacteria can produce indole from tryptophan through the tryptophanase enzyme and have the ornithine decarboxylase enzyme MIO test (Motility, Indole, Ornithine) (Tantu et al., 2013).

In the gelatin test, bacterial isolates from heart samples showed positive results, while bacterial isolates from liver and kidney samples showed negative results. Some bacteria have the gelatinase enzyme with gelatin unable to form and will become liquid (Anggraini et al., 2016).

The results of the MR (Methyl Red) test showed that the three bacterial isolates produced different results. Bacterial isolates from liver and kidney samples showed negative results. While bacterial isolates from heart samples showed positive results. The VP test results (Voges Proskauer) on bacterial isolates from heart samples showed negative results. Meanwhile, bacterial isolates from liver and kidney samples showed positive results. The MR test is to see the ability of bacteria to oxidize glucose by producing acid at high concentrations, and the VP test to detect acetoin in bacterial cultures. A positive result will indicate a change in color to red, while a yellow-brown color indicates a negative result (Hemraj et al., 2013).

In the $\mathrm{OF}$ test (oxidative or fermentative), the three isolates showed a change in the color media from blue to yellow, both in the tube with paraffin or not. The principle of the oxidative/fermentative test of the media covered 
with paraffin changes color from blue to yellow, so bacteria can utilize carbohydrates in anaerobic conditions and are said to be fermentative (Purnamawati, 2016).

In the TSIA (Triple Sugar Iron Agar) test, the three bacterial isolates had a color change, red on the slant (oblique part) that showed the bacteria are saline (alkaline), and yellow on the butt (stem part) that showed the bacteria are acidic (acidic). The three isolates did not produce $\mathrm{H}_{2} \mathrm{~S}$. Bacterial isolates from liver and kidney samples showed gas, and bacterial isolates in the heart samples had no gas. TSIA media used to determine the ability of bacteria to use glucose, lactose, sucrose, and the ability of bacteria to produce gas or hydrogen peroxide $\left(\mathrm{H}_{2} \mathrm{~S}\right)$ (Purnamawati, 2016).

In the Lysine Iron Agar Test, the positive results of lysine deaminase in bacterial isolates from the heart organ. While positive results of lysine decarboxylase on bacterial isolates from the liver and kidneys. The results of the lysine decarboxylase test that showed positive results were purple (purple) isolates on all parts both on the bottom of the media and the slanted part of the media and able to deaminase lysine showeda faded or yellow color change (Rondonuwu et al., 2014).

In the Simmons citrate test, bacterial isolates in the heart samples showed negative results, while the bacterial isolates in liver and kidney samples showed positive results. Simmons citrate media contains the BTB indicator (BromThymol Blue), bacteria use citrate as a carbon source (Chandra and Mani, 2011).

In the urea test, bacterial isolates from liver and kidney samples showed positive results, while bacterial isolates from heart samples showed negative results. The urea test aims to determine the ability of bacteria to convert urea into ammonia (Ulfa et al., 2016).

In the carbohydrate tests, the three phatogenic bacterial isolates showed positive results in the glucose, maltose, and mannitol tests, while the three bacterial isolates showed negative results in sorbitol. In the lactose test, only bacterial isolates from the heart organs showed negative results, while bacterial isolates from the liver and kidneys showed positive results. Aeromonas sp. can ferment glucose and mannitol (Septiama et al., 2010).

In the RS (Rimmler-Shotts) media, the Sp 1. Isolate collected from the heart organ showed green colony color and based on the results of the biochemical test these bacteria were included in the Pleisomonas group. Plesiomonas shigelloides originated from organ samples of the heart. This is also indicated by the clinical symptoms present in Carp (Behera et al., 2018). Whereas, the Sp 2. and Sp 3. isolates were collected from the liver and kidneys showed yellow colony color, which means that the bacteria belonged to the genus Aeromonas. The isolates were grown on Rimmler-Shott media produced yellow without black in the middle of the growing colony, it suggested the sample wasclosely related with A. hydrophila (Saputra, 2018).

\section{Conclussion}

Identification of pathogenic isolates $\mathrm{Sp} \mathrm{1.} \mathrm{from} \mathrm{heart} \mathrm{sample} \mathrm{have} \mathrm{a} \mathrm{close} \mathrm{relationship} \mathrm{with} \mathrm{Plesiomonas}$ shigelloides while the pathogenic isolates $\mathrm{Sp} \mathrm{2.} \mathrm{and} \mathrm{Sp} \mathrm{3.} \mathrm{collected} \mathrm{from} \mathrm{liver} \mathrm{and} \mathrm{kidneys} \mathrm{closely} \mathrm{relate} \mathrm{with}$ Aeromonas hydrophila based on their biochemical tests carried out such as the Simmons Citrate test, Triple Sugar Iron Agar, Oxidative-Fermentative, Motility Indol Ornithine, Lysine Iron Agar, MR-VP, urea, catalase, oxidase, gelatin, confectionery test, and Rimmler-Shotts test.

\section{Acknowledgments}

The author would like to thank to the Biology Department, Faculty of Mathematics and Natural Sciences, University of Bengkulu and Quality Control and Fishery Product Safety Agency (BKIPM) of Bengkulu, as well as to all parties who have helped the completion of this research.

\section{References}

Anggraini, R., Aliza, D., \& Mellisa, S. (2016). Identifikasi Bakteri Aeromonas hydrophila dengan Uji Mikrobiologi pada Ikan Lele Dumbo (Clarias gariepinus) yang Dibudidayakan di Kecamatan Baitussalam Kabupaten Aceh Besar. Jurnal Ilmiah Mahasiswa Kelautan dan Perikanan Unsyiah, 1, 271-286.

Behera, B. K., Bera, A. K., Paria, P., Das, A., Parida, P. K., Kumari, S., \& Bhowmick, S. (2018). Identification and pathogenicity of Plesiomonas shigelloides in Silver Carp. Journal of aquaculture, 4, 314-318.

Chandra, T. J., \& Mani, S. (2011). A study of 2 Rapid Tests to Differentiate Gram Positive and Gram Negative Aerobic Bacteria. Journal of Medical and Allied Sciences, 1, 84-85.

Cowan, \& Steel. (1993). Manual for The Identification of Medical Bacteria, Third Edition, Cambridge University Press, United Kingdom.

Hemraj, V., Diksha, S., \& Avneet, G. (2013). A Review on Commonly used Biochemical Test for Bacteria. Innofare journal of 
life science, 1, 1-7.

Murwantoko, Rozi, Istiqomah. I., \& Kamiso, H. N. (2013). Isolasi, Karakterisasi, dan Patogenitas Bakteri Penyebab Penyakit Pada Gurami (Osphronemus Goramy) Di Kabupaten Bantul. J. Fish Scie, 15, 83-90.

Pratama, R. C., Rosidah, Sriati, \& Ike, R. (2017). Efektifitas Ektrak Biji Rambutan dalam Mengobati Benih Ikan Mas yang Terinfeksi Bakteri Aeromonas hydrophila. Jurnal Perikanan Dan Kelautan, 7(1), 130-138.

Purnamawati, R. (2016). Fish Disease Inspection Methods at Fish Quarantine Center for Quality and Safety Control of Class I Fishery Products in Surabaya. Skripsi, Undergraduate Program of Aquaculture, University of Airlangga.

Putra, A. N., Ningsih, C. W., Nurani, F. S., Mustahal, M., \& Indaryanto, F. R. (2018). Evaluation of Fermentation on Moringa Leaves (Moringa oleifera) as Raw Material on Feed of Tilapia (Oreochromis niloticus). Jurnal Perikanan dan Kelautan, 8(2), 104-113.

Rondonuwu, G., Kepel, B. J., \& Bodhi, W. (2014). Gambaran Bakteri Resistensi $\mathrm{HgCl}_{2}$ Dan Fenil Merkuri yang Diambil dari Feses, Urin, dan Karang Gigi pada Individu yang Tinggal di Daerah Pesisir Pantai di Desa Kema II. Jurnal e-Biomedik $(e B M), 2,1-10$.

Septiama, Sugiarti, B., Aritonang. A., Novel, D., Astri, A., Noor, R., Wahyuni, I., Hapsari, I., Fakriza, I., David, P., Gunardi, A., \& Aryati, E. (2010). Method of Pest Inspection of Quarantined Fish Diseases for Aeromonas salmonicida Bacteria, PUSKARI, Jakarta.

Tantu, W., Reiny, A. T., \& Sammy, N. J. L. (2013). Detection of the Presence Aeromonas sp on Nile Tilapia Cultured in Floating Net Cage in Lake Tondano. J. Budidaya Perairan, 1, 74-80.

Ulfa, Endang, S., \& Mimien, H. (2016). Isolasi dan Uji Sensitivitas Merkuri pada Bakteri dari Limbah Penambangan Emas di Sekotong barat Kabupaten Lombok Barat: Penelitian Pendahuluan. Proceeding Biology Education Conference (ISSN: 2528-5742), 13(1), 12-24.

Yulvizar, Risa, N., \& Agustiana, D. C. (2014). Isolasi dan Karakterisasi Bakteri pada Ikan Kembung (Rastrelliger sp.) Asin Berkitosan. J. Biospecies, 6, 15-19. 